\title{
The Effectiveness Of Play Therapy To Minimize Hyperactive Behavior Of Mild Intellectual Disabilities Student In 1st Grade At SLB C Setya Darma Surakarta Academic Year Of 2018/2019
}

\author{
${ }^{1 *}$ Fauzia Nur Afifah, ${ }^{2}$ Mohammad Anwar, ${ }^{3}$ Hermawan \\ ${ }^{1,2,3}$ Special Education, Sebelas Maret University, Surakarta, Indonesia
}

\begin{abstract}
This research aims to examine the effectiveness of play therapy to minimizing hyperactive behavior of mild intellectual disabilities student in $1^{\text {st }}$ grade at SLB C Setya Darma Surakarta academic year of 2018/2019. The method for this research is using single subject research with particular intervention. The research was using A-B-A design, with first baseline as the original, then intervene the subject, and finally implemented the result to the second baseline afterward. Research subject in this study was a mild intellectual disabilities student who have hyperactive behavior in $1^{\text {st }}$ grade at SLB C Setya Darma Surakarta academic year of 2018/2019. Data collection technique in this research was using observation and interview. This research was analysed with descriptive statistics and visual graph analysis technique. The result showed that there was a reduction to hyperactive behaviour. The average frequency in student's hyperactive behaviour at the first time was 34 times with duration of 20 minutes in 30 minutes lesson. Thereafter, the reduction was showed in the intervene stage to 28.5 with duration of 15 minutes in 30 minutes lesson. Whereas in the second baseline, the average frequency was 18.75 with duration of 10 minutes in 30 minutes lesson. Based on research result, it can be concluded that play therapy is effective in minimizing the behavior of mild intellectual disabilities student in $1^{\text {st }}$ grade at SLB C Setya Darma Surakarta Academic Year of 2018/2019.
\end{abstract}

Keywords: interactive multimedia, the loud reading skills, the child with mental

\section{Preliminary}

Mental disability is an individual who has intelligence that is below average and is accompanied by an inability to adapt behavior that appears in the developmental period. The limited level of intelligence that results in difficulties in attending educational programs in ordinary schools classically, therefore mentally disabed children need educational services specifically that are appropriate to the needs and abilities of children. Every child with special needs has different learning characteristics and needs, so that appropriate grouping is needed so that the teaching goals can be achieved effectively. Children with mental disability are generally grouped based on their level of intelligence, which consists of

\footnotetext{
* Corresponding author: Fauzia Nur Afifah

dirgaandriantamaa@gmail.com

Published online at http://IJDS.ub.ac.id/

Copyright $\odot$ 2019PSLD UB Publishing. All Rights Reserved
}

mild, moderate, and severe mental disability. Mild mentally disabled children need knowledge and skills about daily activities so that they can be independent in caring for themselves. They have less motor censorship, less ability to think abstractly and logically, but have good socialization skills and academic ability can still master certain fields. They include the able group of students, can still be taught to read, write and simple counting even though the results are not optimal.

The limited thinking power experienced by mentally disabled children makes it difficult for them to control whether the behavior carried out in daily activities is reasonable or unnatural. So that to meet all needs as befitting other normal children, mentally disabed children often experience failure or obstacles. As a result, it has an impact on patterns of social interaction, difficulty concentrating and tends to 
move more. Mentally disabled children who have hyperactive behavior can interfere with the learning process in the classroom. Can be identified forms of hyperactive behavior of children with mild mental disability, namely children can not be calm for a long time when sitting in a chair, many find reasons to get out of class, children's attention is very easily diverted to conditions inside and outside the class, unable to last long one activity, always doing or doing assignments very long, in the classroom the child hits the table, talks a lot, interferes with classmates, and is unable to concentrate on receiving lessons from the teacher. Among the behavioral characteristics that emerge are behaviors that do not want to be quiet, unable to sit quietly, always moving, often running around, pacing without any purpose, talking excessively, jumping behavior both during study hours and at school hours. It takes a lot of effort, how to minimize the inappropriate behavior. So that even though they don't have to lose the hyperactive behavior they have, they can at least reduce the actions that make classroom learning ineffective and conducive.

Based on preliminary studies conducted by researchers during the Internship 3 and becoming teachers who handle mild mentally disabed children who have hyperactive behavior, children are very happy and attentive when invited to play and sing children's songs. If the child is asked to play and sing a song, the child will immediately come to the front of the class and be very enthusiastic about the game given. Based on the condition of children who are happy when invited to play and the statement that play can be used as a medium for doing therapy, the researchers chose play therapy as a medium to minimize hyperactivity in mild mentally disabed children at SLB C Setya Darma Surakarta. The application of play therapy in this study is more on motor activity. Motor activity requires a lot of energy to be expelled by children. The selection of this game is based on the influence of therapy to play as a channel for hidden emotional energy and channeling for the needs and desires of children.

Based on the problems described, to assist $\mathrm{S}$ in minimizing hyperactive behavior, especially in reducing excessive talking behavior and increasing sitting resistance, researchers are interested in exploring problems. So this research entitled "The Effectiveness of Play Therapy to Minimize Hyperactive Behavior of Mild Intellectual Disabilities Student in $1^{\text {st }}$ Grade at SLB C Setya Darma Surakarta Academic Year of 2018/2019". It is hoped that through play therapy this can minimize hyperactive behavior and generate enthusiasm for learning.

\section{Research Methodology}

Play Therapy to Minimize Hyperactive Behavior of Mild Intellectual Disabilities Student in $1^{\text {st }}$ Grade at SLB C Setya Darma Surakarta" taking place at the SLB C Setya Darma Surakarta is located on Jalan Mr. Sartono No. 32 Bibis Baru Nusukan, Banjarsari, Surakarta City, Central Java 57135. This research was conducted at SLB C Setya Darma based on the existence of mild mentally retarded children accompanied by hyperactive behavior that is in accordance with the subject criteria needed in research and play therapy has not been applied in an effort to minimize hyperactive behavior in mild mentally retarded children. The study was conducted from February to March 2019.

This type of research uses experimental research in the form of Single Subject Research (SSR). Experiments are studies that are intended to determine the effect of certain treatments on others under controlled conditions. The design used in this single subject research is the A-B-A design. In this design the first step the researcher defines is the target behavior as behavior that can be accurately measured. The second step of the researchers measured the baseline (A1) which is a condition where the measurement of target behavior was carried out before the intervention was given. The third step, the researcher intervenes (B) and measures the target behavior. The fourth step, the researchers took measurements as in the baseline phase (A2) after they were no longer given intervention. Baseline conditions and interventions are repeated until the data is stable.

Variables are everything that will be the object of observation in research. The research variable is an attribute or the nature or value of a person, object or activity that has certain 
variations determined by the researcher to be studied and then concluded. As for the dependent variable (target behavior) in this study is hyperactive behavior. In this study, the subjects were mild mentally retarded children who had hyperactive behavior in I grade at SLB C Setya Darma Surakarta. An 8 years old child with male sex who exhibits hyperactive behavior such as talking excessively and often leaving a seat in the classroom.

Data collection technique is a method used by researchers to obtain research data. The data collection technique used is using structured observation, where observations use structured and ready-to-use instruments by measuring the frequency and duration of hyperactive behavior carried out during one lesson or 30 minutes. And using unstructured interviews to dig up information about the subject. By observing, calculating the frequency, and duration of hyperactive behavior of students in one event so that it can be seen on the graph.

Data analysis is a review and decomposition of data to produce conclusions. Data analysis in this study used descriptive statistical techniques and graphical visual analysis (Visual Analysis of Data Graphs). Descriptive statistics are ways of describing the activities of collecting, compiling, processing, and presenting data in the form of tables, graphs, or diagrams to provide a clear picture. While visual graph analysis describes the data into a graph, then the data is analyzed based on the components in each condition, namely baseline (A1), intervention (B) and baseline (A2). For the purposes of visual data analysis 6 components are needed in the analysis in conditions covering the length of the condition, estimating the direction trend which is the change in each data. The estimation in this study uses the Free Hand method. Estimation of direction stability with a criterion of $15 \%$, data trace with marked (+) or (-), stability level range and level of change. The final determination of changes in the level is measured at the end of the observation at each stage. Large changes in the level between the baseline phase and the intervention phase are important indicators of changes in ability to compare two fractions. In the analysis between conditions that must be considered more, namely overlap. Overlap is a data pattern that describes the state of a cross-phase. If there is an overlap of meaning, there are similarities between the baseline and intervention phase data, meaning that changes do not occur. If the smaller percentage overlap, the better the influence of intervention on the target behavior. To see the effect of intervention, it will be easier to read by looking at changes in the level of direction trends after being given an intervention.

\section{Results and Discussion}

This study was conducted 14 times where A1 was the baseline (A1) before the intervention was given for 4 meetings, then in the Intervention condition (B) it was the intervention stage or treatment ie 6 meetings and the baseline condition (A2) was the baseline stage after not being given intervention as much as 4 meetings. Results in each research phase can be seen from the table 1 .

Table 1 Result of Each Step Research

\begin{tabular}{|c|c|c|c|c|c|}
\hline \multirow[t]{2}{*}{ Name } & \multicolumn{4}{|c|}{ Baseline 1} & \\
\hline & 1 & 2 & 3 & 4 & \\
\hline \multirow[t]{7}{*}{ MJS } & 37 & 36 & 36 & 34 & \\
\hline & \multicolumn{5}{|c|}{ Intervensi } \\
\hline & 5 & 6 & 7 & 8 & 9 \\
\hline & 32 & 31 & 30 & 29 & 26 \\
\hline & \multicolumn{4}{|c|}{ Baseline 2} & \\
\hline & 11 & 12 & 13 & 14 & \\
\hline & 20 & 20 & 18 & 17 & \\
\hline
\end{tabular}

\section{Analysis in Conditions}

The conditions to be analyzed in this study are the baseline condition (A1) which is the initial condition of the child before the play therapy treatment is given, the intervention condition (B) which is a condition given the treatment of play therapy to minimize the hyperactive behavior of mild mentally retarded children and the condition of besline (A2) is the condition of the child not given treatment. Analysts in this condition can be illustrated in the following graph: 


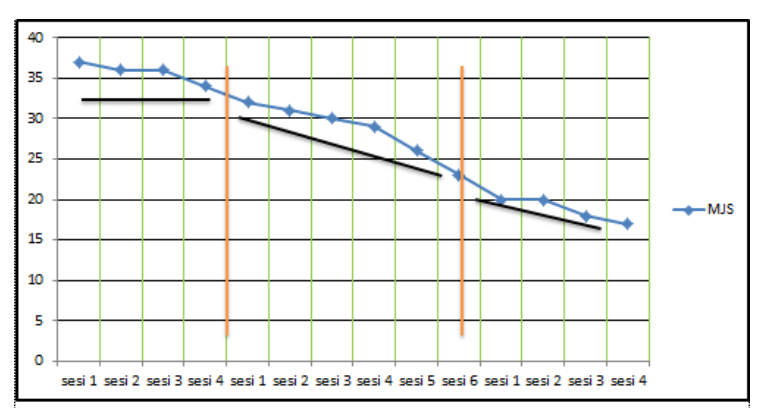

Fig 1. Hyperactive Behavior Frequency

Baseline conditions 1 (A1) before being given treatment, the length of the condition is the number of observations made 4 times. Estimation of trend direction using split-middle method, at baseline 1 (A1) graph shows hyperactive behavior with stable direction tendency or behavior does not experience a drastic increase or decrease. Stability trends at the baseline (A1) stage have a stability range of 5.55 , mean 35.75 , upper limit of 38.525 , and lower limit of 32.975 , with a tendency of $100 \%$ stability. Data tracks at baseline (A1) level horizontally with stability levels and ranges from 37 to 34 which means stable or no changes in the form of increasing or decreasing the frequency of hyperactive behavior so that the level of change in hyperactive behavior $37-34=+3$. Because the data is stable, the researcher continues to the intervention stage (B).

Intervention condition (B) when given play therapy treatment to minimize hyperactive behavior, which was analyzed under conditions including the length of condition 6 times. The estimated trend in the direction of direction is decreasing which means that there is a decrease in the frequency of hyperactive behavior. The stability tendency in the intervention stage (B) has a stability range of 4.8 , mean 28.5 , upper limit of 30.9 , and lower limit of 26.1 with a stability tendency of $50 \%$. The trace condition at this stage has decreased with the stability level and the range $32-23$ means that it is unstable because it has a very drastic decrease in the frequency of behavior which has a level of behavior change $32-23$ $=+9$.

Baseline condition 2 (A2) after being given treatment or treatment is terminated, the length of the condition is carried out 4 times with an estimate of the downward trend. The stability tendency in baseline 2 (A2) has a stability range of 3 , mean 18.75 , upper limit of 20.25, and lower limit of 17.25 with a tendency of $100 \%$ stability. The data trace at this stage has decreased with the stability level and the range of 20-17 means stable because it has decreased the frequency of non-drastic behavior which has a level of behavior change $20-17=+3$.

\section{Inter-Condition Analysis}

Whether or not the influence of intervention on the subject depends on aspects of level changes and the size of the overlap that occurs between the two conditions analyzed. The components to be analyzed are the number of variables changed, changes in direction of trends, changes in trends in stability, level of change, and overlap of data. It can be seen that the change in direction tendency in the baseline 1 (A1) stage is stable, while in the intervention stage (B) the frequency of the child's hyperactive behavior decreases, as well as in the baseline stage (A2) the trend changes in direction so that the intervention has a positive effect on the changed variable - Changes in the stability trend in the baseline (A1) condition with a range of 3734 shows the stability of the trend towards stable change. Whereas in the intervention condition (B) with a range of $32-23$, the stability of the direction tendency is unstable but the trend of change is decreasing. Likewise, at baseline 2 (A2) with a range of 20-17, the stability of the direction tendency is stable with changes decreasing.

Level changes can be calculated by first determining the last session point data on baseline 1 (A1), the first session on intervention conditions (B), and the last session on intervention conditions (B), and the first session on baseline 2 (A2), then calculating the difference. In subject $S$ the last session value of baseline 1 (A1) is 34 and the value of the first session of the intervention stage (B) is 32 then calculate the difference between the two (32 - 34) then obtained $(+2)$. Because this change decreases while the target is to minimize hyperactive behavior then it is marked (+). 
The value of the last session of intervention (B) is 23 and the value of the first session of the baseline stage 2 (A2) is 20 then calculate the difference between the two $(20-23)$ then obtained $(+3)$.

Data overlap at baseline 1 (A1) to the intervention stage (B) there is no intervention value (B) which is in the baseline range $1(\mathrm{~A} 1)$, it can be concluded that the data obtained is good because there is no data in the baseline range 1 with the percentage of overlap is $0 \%$. Whereas the overlap data in the intervention stage (B) to the baseline (A2) stage also has no intervention value (B) which is in the baseline range (A2) so it can be concluded that the data obtained is good because there are no data in the intervention range with the overlap percentage is $0 \%$.

\section{Discussion}

Based on the research that has been done to mild mentally retarded children who have hyperactive behavior in I grade at SLB C Setya Darma Surakarta to minimize hyperactive behavior in the classroom during the learning process through play therapy. Measurements at baseline 1 are intended to determine the frequency and duration of $\mathrm{S}$ hyperactive behavior during 1 lesson (30 minutes). Measurements are made by observing the frequency and duration of students' hyperactive behavior. The results of observations at baseline 1 were carried out 4 times, the first day of $\mathrm{S}$ hyperactive behavior was 37 , second day 36 , third day 36, and fourth day 34 . The results obtained at baseline 1 indicate that $\mathrm{S}$ has hyperactive behavior that is very disturbing during the lesson, making the learning process not conducive. The assessment results from Appraiser 1, Appraiser 2, and Appraiser 3 about hype-active $\mathrm{S}$ behavior were 34 times with a duration of 20 minutes in 1 lesson (30 minutes). $\mathrm{S}$ hyperactive behavior at this stage is still very high and can be said to be very disturbing so that the learning process in the classroom is not conducive. This is also reinforced by the opinion of Putranto (2015: 85) which states that in the condition of students who have hyperactive behavior, usually teachers experience difficulties in organizing and educating. After measuring at the baseline 1 stage, it will then be followed by treatment or intervention.

Intervention activities were carried out with play therapy for 6 consecutive times, in which each intervention was carried out for 30 minutes. The game is in the form of a game of congklak, coloring, crunching, pinching the ball, and guessing cards. This intervention with play therapy not only seeks to minimize hyperactive behavior by playing but also uses elements of singing and giving reinforcement. The results obtained from the intervention stage showed a decrease in hyperactivity that was quite good compared to when measuring baseline 1 or before intervention. The average frequency obtained by $S$ at the time of intervention showed a decrease compared to the baseline stage 1 . At the baseline 1 stage, $\mathrm{S}$ gets an average frequency of 34 , and at the time of intervention the average frequency becomes 28.5. The three assessors agreed that at the intervention stage the frequency of $S$ hyperactive behavior was reduced and indicated the effectiveness of play therapy to minimize the hyperactive behavior of mild mentally retarded children.

After carrying out the intervention activities, then the baseline stage 2 was measured without intervention. This measurement is intended to determine the impact caused by interventions that are not given anymore. In this measurement, the frequency of hyperactive behavior $\mathrm{S}$ has decreased. At the time of the $S$ intervention the average frequency of hyperactivity behavior was 28.5 and at the baseline stage 2 the average frequency of hyperactive behavior was 18.75. The reduction in hyperactive behavior that occurs at the baseline stage 2 is estimated because of the persistent positive influence resulting from the intervention.

Based on the results of the research and discussion, by looking at the results of baseline 1, intervention, and baseline 2, it can be concluded that play therapy is effective in minimizing the hyperactive behavior of mild mentally retarded children in the SLB C Setya Darma Surakarta. This proves the statement of Isbani (1985: 3) which states that the function of play therapy is to reduce, if possible remove obstacles, disturbances, and emotional stress and psychological stress suffered by children.

Cite this as:

Afifah, Fauzia Nur, Anwar, Mohammad, Hermawan. The Effectiveness Of Play Therapy To Minimize Hyperactive Behavior Of Mild Intellectual Disabilities Student In 1st Grade At Slb C Setya Darma Surakarta Academic Year Of 2018/2019 .Indonesian Journal of Disability Studies (IJDS).2019: Vol. 6(2): PP 169-175. 
This is based on the idea that in situations where children will be able to express all obstacles, disturbances, emotional stresses and mental stress, the child will be easily directed.

\section{Conclusion}

Based on theoretical studies and supported by analysis of research results and referring to the formulation of the problems described in the previous chapter, it can be concluded that effective play therapy to minimize the hyperactive behavior of mild mentally disability children in the SLB C Setya Darma Surakarta academic year of 2018/2019 play therapy effective in minimizing the hyperactive behavior of mild mentally retarded children with a decrease in the frequency of hyperactive behavior after being given an intervention and the decline persists when the intervention is removed.

\section{Suggestion}

Based on the results of the research that has been described, the researcher intends to provide suggestions that can be beneficial for students, teachers, agencies, and subsequent researchers. The suggestions given are as follows:

1. Students

Students are expected to be able to take lessons in class well, obey the teacher's orders, and increase their learning motivation.

2. Teachers

Teachers should provide security and opportunities for children to explore and recognize space, game objects, themselves and their relationship to the environment. The teacher can modify play therapy by creating new games that are more fun and can be adapted to the theme of the lesson.

3. School

The school is expected to be able to support every innovation developed by the teacher by providing a special safe and comfortable playground, because playing for children will produce the ability to build relationships with others, develop themselves, and express themselves.

4. Next researchers

Future researchers are expected to be more prepared in the process of retrieving, collecting, and processing data so that research can be carried out better.

\section{References}

Adriana, Dian. (2013). Tumbuh Kembang dan Terapi Bermain pada Anak. Jakarta: Salemba Medika.

Arifin, Zainal. (2014). Penelitian Pendidikan (Metode dan Paradigma Baru). Bandung: PT Remaja Rosdakarya.

Arikunto, Suharsimi. (2006). Prosedur Penelitian Suatu Pendekatan dan Praktek. Jakarta: Rineka Cipta.

Asmani, Jamal Ma'mur. (2011). Tuntunan Lengkap Metodologi Praktis Penelitian Pendidikan. Jogjakarta: Diva Press.

Astuti, Puji. (2014). Mengenal Karakteristik Anak Berkebutuhan Khusus Menuju Layanan Belajar. Jakarta: Kementerian Pendidikan dan Kebudayaan.

Atmaja, Jati Rinarki. (2018). Pendidikan dan Bimbingan Anak Berkebutuhan Khusus. Bandung: PT Remaja Rosdakarya.

Azmira, Via. (2015). A Gift: Anak HiperaktifMemahami, Mendeteksi, Terapi, dan Pola Asuh yang Tepat Bila Memiliki Anak Hiperaktif. Yogyakarta: Rapha Publishing.

Azwar, Saifuddin. (2014). Reliabilitas dan Validitas. Yogyakarta: Pustaka Pelajar.

Charner, Murphy, Ford. (2006). Permainan Kreatif pengisi Waktu Luang untuk Anak Usia 3-6 Tahun. Jakarta: Erlangga.

Delphie, Bandi. (2012). Pembelajaran Anak Tunagrahita (Suatu Pengantar dalam Pendidikan Inklusi). Bandung: PT Refika Aditama.

(2009). Layanan Perilaku Anak Hiperaktif. Sleman: PT Intan Sejati Klaten.

Efendi, Mohammad. (2006). Pengantar Psikopedagogik Anak Berkelainan. Jakarta: PT Bumi Aksara. 
Isbani. (1985). Play Therapy (Terapi Bermain). Surakarta: Universitas Sebelas Maret.

Kemis \& Rosnawati, Ati. (2013). Pendidikan Anak Berkebutuhan Khusus Tunagrahita. Jakarta: PT Luxima Metro Media.

Kosasih, E.. (2012). Cara Bijak Memahami Anak Berkebutuhan Khusus. Bandung: Yrama Widya.

Kusaeri \& Suprananto. (2012). Pengukuran dan Penilaian Pendidikan. Jakarta: Graha Ilmu.

Maolani, Rukaesih A., dan Ucu Cahyana. (2016). Metodologi Penelitian Pendidikan. Jakarta: PT RajaGrafindo Persada.

Martin, Grant L.. (2008). Terapi untuk Anak ADHD (untuk anak Hiperaktif, sulit

Berkonsentrasi, Tidak aktif, kurang perhatian, dan lain-lain). Jakarta : PT Bhuana Ilmu Populer.

Muhammad, Jamila K.A. (2008). Special Education for Special Children; Panduan Pendidikan Khusus Anak-Anak dengan Ketunaan dan Learning Disabilities. Jakarta: PT Mizan Publika.

Munzayanah. (2000). Tunagrahita. Surakarta: UNS Press.

Musfiqon. (2015). Panduan Lengkap Metodologi Penelitian Pendidikan. Jakarta: PT Prestasi Pustakaraya.

Putranto, Bambang. (2015). Tips Menangani Siswa yang Membutuhkan Perhatian Khusus: Ragam Sifat dan Karakter Siswa "Spesial" dan Cara Menanganinya. Yogyakarta: Diva Press.

Putri, Nola Intan. (2015). Efektivitas Bermain Tebak Isi Gelas untuk Meningkatkan Ketahanan Duduk Anak Hiperaktif di Kelas Persiapan SLB FAN Redha Padang. Jurnal Ilmiah Pendidikan Khusus, Vol. 4, 278-286. Diperoleh pada tanggal 13 Desember 2018 dari http://ejournal.unp.ac.id/index.php/jupekhu/arti cle/view/7065

Resnandari, Endah. (2014). Upaya Mengurangi Perilaku Hiperaktif dan Impulsive Melalui Penerapan Variasi Terapi Permainan di Sela
Pembelajaran pada Siswa ADHD Kelas III-A SLB Autis Alamanda Surakarta. Jurnal Teknologi Pendidikan, Vol. 1. Diperoleh tanggal 7 Desember 2018 dari https://scholar.google.co.id/citations?user $=4 \mathrm{k} 0$ R_iUAAAAJ\&hl=id

Saputro, Heri dan Intan Fazrin. (2017). Anak Sakit Wajib Bermain di Rumah Sakit: Penerapan Terapi Bermain Anak Sakit, Proses, Manfaat dan Pelaksanaannya. Ponorogo: Forum Ilmiah Kesehatan (FORIKES).

Sugiyono. (2017). Metode Penelitian Pendidikan: Pendekatan Kuantitatif, Kualitatif, dan $R \& D$. Bandung: Alfabeta.

Sukmadinata, Nana Syaodih. (2011). Metode Penelitian Pendidikan. Bandung: PT Remaja Rosdakarya.

Susanto. (2006). Metode Penelitian Sosial. Surakarta: UNS Press.

Suyadi. (2014). Teori Pembelajaran Anak Usia Dini Dalam Kajian Neurosains. Bandung: PT Remaja Rosdakarya.

Utari, Debi Puji dan Marlina. (2018). Mengurangi Perilaku Hiperaktif pada Anak Tunagrahita Ringan Melalui Teknik Extinction. Jurnal Penelitian Pendidikan Kebutuhan Khusus, Vol. 6. Diperoleh pada tanggal 19 Desember 2018 dari ejournal.unp.ac.id/index.php/jupekhu/article/vie w

Wijaya, Ardhi. (2013). Teknik Mengajar Siswa Tunagrahita (Disabilitas Intelegensi Gangguan Intelektual). Yogyakarta: Penerbit Imperium.

Yusuf, Syamsu dan Nani Sugandhi. (2012). Perkembangan Peserta Didik. Jakarta: PT Raja Grafindo Persada.

Zellawati, Alice. (2011). Terapi Bermain untuk Mengatasi Permasalahan pada Anak. Majalah Ilmiah Informatika, Vol. 2. Diperoleh pada tanggal 7 Desember 2018 dari www.unaki.ac.id/ejournal/index.php/majalahilmiah-informatika/article/ 